\title{
KNOWLEDGE OF BREASTFEEDING TECHNIQUE AMONG POSTPARTUM WOMEN
}

\author{
Lilis Mamuroh ${ }^{1}$, Sukmawati ${ }^{2}$, Furkon Nurhakim ${ }^{3}$ \\ ${ }^{1,2,3}$ PSDKU Garut Universitas Padjadjaran, Garut, Indonesia \\ Correspondence: lilis.mamuroh65@gmail.com
}

\begin{abstract}
Problems in breastfeeding are caused by several causes including nipples issues (flat or injury), swollen breasts, and breast inflammation. These problems may occur due to improper breastfeeding techniques. The purpose of the research was to obtain an overview of mother's knowledge about the correct technique of breastfeeding. The research method uses descriptive approach, there were 20 women involved in this study. The results showed that 5 respondents $(25 \%)$ had good knowledge, $3(15 \%)$ had moderate knowledge, $12(60 \%)$ had insufficient knowledge. This study also examined knowledge based on age, results showed that the majority of respondents aged 20-35 years (64.28\%) had a lack of knowledge. Based on the background of formal education, the study revealed that most elementary school graduates were less knowledgeable about breastfeeding techniques $(70 \%)$. Knowledge about breastfeeding techniques was also lacking in prim gravida respondents $(100 \%)$. It can be concluded that respondents' knowledge is still lacking in breastfeeding techniques. Increasing women's knowledge about breastfeeding techniques is needed because a good nutrition from breast milk will improve and support baby's health.
\end{abstract}

Keywords: breastfeeding techniques, knowledge, postpartum

\section{INTRODUCTION}

Breastfeeding is a natural process, the mother is naturally able to breastfeed her baby without having to read a book about breastfeeding. Along with the development of the modern era, science and technology are growing rapidly. However, natural things that underlie a person's attitude and behavior, including the nature of a woman to breastfeed her baby decreases. In science and knowledge, breastfeeding plays an important role in maintaining human life (Roesli, 2000). Problems with breastfeeding can be caused by problems with babies and mothers. Problems related to breastfeeding can occur from pregnancy, postpartum, and postpartum periods (Widiasih, 2008). One of the causes of breastfeeding problems is due to nipple issues, which is short of flat nipples, nipples abrasions that causing pain to the mother while breastfeeding. In addition, the problem of breast infection is markedly not smoothly flowing breast milk, swollen breasts, and blocked ducts in the breast.

The condition of the mother's breast, breastfeeding techniques are other factors that influence the breastfeeding process. Inappropriate breastfeeding techniques can cause 
Lilis Mamuroh : Knowledge of Breastfeeding Technique among Postpartum Women

problems when breastfeeding. The impact on infants is that babies rarely suckle, the frequency of breastfeeding is less affecting breastmilk production, the long-term impact of babies lacking nutrition. An appropriate breastfeeding technique is very important. The purpose of this study was to obtain a description of postpartum knowledge about breastfeeding techniques.

\section{METHODS}

This research was a quantitative descriptive study. The population in this study were postpartum mothers who were hospitalized in the Kalimaya ward at Dr. Slamet Garut hospital. This study applied a cross-sectional approach. The number of samples was 20 postpartum mothers, the first-third day of hospitalization, normal and sectio caesarean delivery. Data was collected by researchers in collaboration with nurses. Respondents filled out a questionnaire about breastfeeding techniques. Respondents' answers were coded, scored, then categorized into good, moderate, low level of knowledge. Data were analyzed using percentages and then presented in table form. 


\section{RESULTS}

The level of knowledge about breastfeeding techniques is presented in table 1.

Table 1. Knowledge of Mother about Breastfeeding Techniques

\begin{tabular}{ccc}
\hline Knowledge & f & $\%$ \\
\hline Good & 5 & 25 \\
Moderate & 3 & 15 \\
Low & 12 & 60 \\
\hline Total & 20 & 100 \\
\hline
\end{tabular}

The results showed that $25 \%$ of respondents had good knowledge, and most respondents lacked knowledge about breastfeeding techniques (60\%).

The level of respondents' knowledge about breastfeeding techniques based on the characteristics of the respondents is explained in tables $2,3,4$, and 5 .

Table 2. Postpartum Mothers' Knowledge about Breastfeeding Technique by Ages

\begin{tabular}{cccccccccc}
\hline No & Ages & \multicolumn{2}{c}{ Low } & \multicolumn{2}{c}{ Moderate } & \multicolumn{2}{c}{ Good } & \multicolumn{2}{c}{ Total } \\
\cline { 2 - 10 } & & $\mathrm{f}$ & $\%$ & $\mathrm{f}$ & $\%$ & $\mathrm{f}$ & $\%$ & $\mathrm{f}$ & $\%$ \\
\hline 1 & $<20$ & 3 & 100 & 0 & 0 & 0 & 0 & 3 & 100 \\
2 & $21-35$ & 9 & 64,28 & 2 & 14,28 & 3 & 21,42 & 14 & 100 \\
3 & $>35$ & 0 & 0 & 1 & 33,33 & 2 & 66,66 & 3 & 100 \\
\hline & Total & 12 & 60 & 3 & 15 & 5 & 25 & 20 & 100 \\
\hline
\end{tabular}

Table 2 shows that all mothers aged $<20$ years had a lack of knowledge about breastfeeding technique, the similar trend found in mothers aged 21-35 years, most of them (64.28\%) had low knowledge. In contrast, women age 35 and more had a good knowledge of breastfeeding techniques. 
Table 3. Postpartum Mothers' Knowledge about Breastfeeding Technique by The Level of Formal Education

\begin{tabular}{cccccccccc}
\hline No & Level of & \multicolumn{2}{c}{ Low } & \multicolumn{2}{c}{ Moderate } & \multicolumn{2}{c}{ Good } & \multicolumn{2}{c}{ Total } \\
& Education & $\mathrm{f}$ & $\%$ & $\mathrm{f}$ & $\%$ & $\mathrm{f}$ & $\%$ & $\mathrm{f}$ & $\%$ \\
\hline 1 & Uneducated & 0 & 0 & 0 & 0 & 0 & 0 & 0 & 0 \\
2 & Elementary & 7 & 70 & 3 & 30 & 0 & 0 & 10 & 100 \\
3 & Junior High Sc & 2 & 50 & 0 & 0 & 2 & 50 & 4 & 100 \\
4 & Senior High Sc & 3 & 60 & 0 & 0 & 2 & 40 & 5 & 100 \\
5 & University & 0 & 0 & 0 & 0 & 1 & 100 & 1 & 100 \\
\hline & Jumlah & 12 & 60 & 3 & 15 & 5 & 25 & 20 & 100 \\
\hline
\end{tabular}

Table 3 shows all respondents had attended school. Most of them attended elementary school (70\%). Data shows that most have insufficient knowledge at all levels of basic education, namely elementary, middle and high school (70\%, 50\%, and 60\%) respectively.

Table 4. Postpartum Mothers' Knowledge about Breastfeeding Technique by Occupation

\begin{tabular}{cccccccccc}
\hline \multirow{2}{*}{ Oc } & \multirow{2}{*}{ Occupation } & \multicolumn{2}{c}{ Low } & \multicolumn{2}{c}{ Moderate } & \multicolumn{2}{c}{ Good } & \multicolumn{2}{c}{ Total } \\
\cline { 3 - 10 } & & $\mathrm{f}$ & $\%$ & $\mathrm{f}$ & $\%$ & $\mathrm{f}$ & $\%$ & $\mathrm{f}$ & $\%$ \\
\hline 1 & Jobless & 12 & 63,15 & 3 & 15,78 & 4 & 21,05 & 19 & 100 \\
2 & Working & 0 & 0 & 0 & 0 & 1 & 100 & 1 & 100 \\
\hline & Total & 12 & 60 & 3 & 15 & 5 & 25 & 20 & 100 \\
\hline
\end{tabular}

Table 4 presents that the majority of respondents did not work. The level of knowledge of mothers who do not work on breastfeeding techniques is lacking $(63.15 \%)$. There is only 1 respondent who works and has a good level of knowledge about breastfeeding techniques. 
Lilis Mamuroh : Knowledge of Breastfeeding Technique among Postpartum Women

Table 5. Postpartum Mothers' Knowledge about Breastfeeding Technique by The Number of Children

\begin{tabular}{cccccccccc}
\hline No & Paritas & \multicolumn{2}{c}{ Kurang } & \multicolumn{2}{c}{ Cukup } & \multicolumn{2}{c}{ Baik } & \multicolumn{2}{c}{ Total } \\
& & $\mathrm{f}$ & $\%$ & $\mathrm{f}$ & $\%$ & $\mathrm{f}$ & $\%$ & $\mathrm{f}$ & $\%$ \\
\hline 1 & 1 & 9 & 100 & 0 & 0 & 0 & 0 & 9 & 100 \\
2 & $2-4$ & 3 & 37,5 & 2 & 25 & 3 & 37,5 & 8 & 100 \\
3 & $>5$ & 0 & 0 & 1 & 33,33 & 2 & 66,66 & 3 & 100 \\
\hline & Jumlah & 12 & 60 & 3 & 15 & 5 & 25 & 20 & 100 \\
\hline
\end{tabular}

The results showed that mothers with parity more than 5 had good knowledge about breastfeeding techniques, and primigravid had less knowledge.

\section{DISCUSSION}

Based on this study findings postpartum mothers have limited knowledge about the technique of breastfeeding. It may due to the belief that breastfeeding is a natural instinct, and does not need to be studied. Mothers feel they would be able to learn by themselves, even though most of the respondents were primigravid and have not had breastfeeding experience.

The majority of respondents attended elementary school, health education programs form health professionals were limited, it may be impacted by insufficient respondents' knowledge. Information facilities such as media for health education are limited, so the role of health workers is still also limited. According to Notoatmodjo (2003), knowledge can be influenced by several factors, including experience, level of education, beliefs, and facilities. The experience that has been gained can broaden one's knowledge, and the level of education is also influential. Someone who is more educated will have extensive knowledge while breastfeeding beliefs that really affect and are supported by the availability of facilities, the trust, and motivation of mothers to breastfeed their babies.

According to the age of respondents, the results of the study showed that teenage pregnancies had less knowledge than mothers ages 35 and more, they had an understanding of breastfeeding techniques. This proves that one's knowledge is not measured by age, older 
Lilis Mamuroh : Knowledge of Breastfeeding Technique among Postpartum Women

age does not guarantee better knowledge but has more experience, more experience will add insight and make knowledge better. Yet, there is a possibility that younger age having known better, and sometimes other people's experiences can be used as a source of knowledge.

The majority of patients in the Kalimaya ward were rural patients who referred from PHC to hospitals around Garut. One of the characteristics of rural communities is the low level of education. Based on these data, the majority of postpartum mothers in the Kalimaya Hospital of Dr. Slamet Garut attended elementary school graduates, only a few breastfeeding mothers had the correct knowledge of breastfeeding techniques, several factors that supported the lack of knowledge about breastfeeding. Health education from health workers is limited. There were respondents who get knowledge. According to Notoatmodjo, a person's knowledge is influenced by education, higher education will have broad knowledge compared to a low level of education.

Work

Based on the respondent's work, it was found that only 1 out of 20 respondents worked and had good knowledge. 19 postpartum mothers are housewives, 12 of them had lack of knowledge, 3 postpartum women had the moderate knowledge and 4 postpartum women had good knowledge. Viewed from the health system model, according to Anderson in Notoatmodjo (2003) describes the model of health trust, in this model one of the main categories that influence health behavior is the characteristics of predisposition, including an individual occupation. From the results of these studies, it can be seen that having a good knowledge was depends on the willingness of each individual not the status of the job. It can be seen that the level of respondents' understanding of breastfeeding technique was varied. 
Lilis Mamuroh : Knowledge of Breastfeeding Technique among Postpartum Women

Parity

This study found 9 out of 20 respondents were prim gravida and had a low level of knowledge, and women who have parity 3 or more had a good understanding of breastfeeding technique. According to Notoatmodjo (2003) that the influence of one's own experience would influence an individual's current or later behavior. Parity is related to the experience in breastfeeding, It can be seen that experience can be attributed to one's knowledge. More experience usually has better knowledge, but there is the possibility that women who do not have breastfeeding experience may learn from others other people's experiences or get information from the media.

\section{CONCLUSION}

It can be concluded that respondents' knowledge is varied, and the majority of them have limited health literacy of breastfeeding techniques. Increasing women's knowledge about breastfeeding techniques is needed because a good nutrition from breast milk will improve and support baby's health and development.

\section{REFERENCES}

Arikunto S, 2006 Prosedur Penelitian Suatu Pendekatan Praktik Jakarta. Rineka Cipta ASI Eklusif. Materi Pelatihan Orientasi Promosi ASI bagi petugas Puskesmas, 2006 Modi Briten \& Hogg 2001. Menyusui Cara Mudah, Praktis dan Nyaman Jakarta : Arcan Notoatmodjo, Soekdijo . 2003. Ilmu Kesehatan Masyarakat Jakarta,: Rineka Cipta. Notoatmodjo, Soekidjo. 2005. Metodologi Penelitian Kesehatan, Jakarta : Rineka Cipta. Notoatmodjo, Soekidjo, 2003. Pendidikan dan Perilaku kesehatan, Jakarta : Rineka Cipta Nursalam, P, 2001, Pendekatan Praktis Metodologi Riset Keperawatan, Jakarta : Sagung Seto. 
Lilis Mamuroh : Knowledge of Breastfeeding Technique among Postpartum Women

Perinasia, 2004, Tehnik Menyusui yang benar-benar tenang pada akhir menyusui .

Roesli, Utami, 2005 Mengenal ASI Ekslusif, Jakarta : Trubus Agriwidya

Roesli, Utami, 2005, Panduan Praktis Menyusui, Jakarta : Puspa Swara

Widiasih R. (2008). Masalah-masalah dalam menyusui. Seminar manajemen laktasi.

Bandung Fakultas Ilmu Keperawatan Universitas Padjajaran. http://pustaka.unpad.ac.id/wpcontent/uploads/2009/09/masalah-masalah_dalam_menyusui.pdf 